\title{
Engelli Çalışanların İşyeri ve İşverenine Yönelik Görüşlerinin İncelenmesi ${ }^{1}$
}

\author{
Arzu ANIL* \\ Ereğli Rehberlik Araştırma Merkezi, Konya / Türkiye, \\ anil-a@outlook.com, ORCID: 0000-0002-9747-5656

$$
\text { Dr. Öğr. Üyesi Ş. Şenay İLiK }
$$

Necmettin Erbakan Üniversitesi, Ahmet Keleşoğlu Eğitim Fakültesi, Özel Eğitim Bölümü, Konya / Türkiye, senayilik@gmail.com, ORCID: 0000-0001-7092-379

\section{$\ddot{O} z$}

$\mathrm{Bu}$ araştırmanın amacı, engelli çalışanların iş yeri ve işverenine yönelik görüşlerini belirlemektir. Engelli çalışanların işverenlere yönelik görüşlerinin belirlenmesinde nitel araştırma modeli kullanılmıştır. Araştırma örneklemini Konya ili Selçuklu, Meram ve Ereğli ilçelerinde özel sektörde ve devlet kurumundaki 26 iş yerindeki 35 engelli çalışan oluşturmaktadır. Engelli çalışanların görüşleri yarı yapılandırılmış görüşme formu aracılı̆̆ıyla alınmış ve nitel-betimsel içerik analizleri yapılmıştır. Araştırma sonunda on dört engelli çalışan işverenlerin sorunlara yaklaşımı konusunda işverenlerin işlerle ilgili olarak görev paylaşımı yaptıklarını, iş yükünü azalttıklarını, öğrenme süresi tanıdıklarını, işin öğretimini yaptıklarını ifade etmişlerdir. Beş engelli çalışan ise işverenlerin iş yerinde kendilerine sormadan işler verdiklerini, görev dağılımında adil davranmadıklarını, işleri tek başına yaptıklarını ya da işverenlerin, kendilerinin sahip olduğu yeterlilikler, engel türü ve seviyeleri dışında işler verdiklerini dile getirmişlerdir. Araştırma sonuçları doğrultusunda engelli bireylerle ilgili okuldan iş hayatına

\footnotetext{
${ }^{1} \mathrm{Bu}$ araştırma, birinci yazarın ikinci yazar danışmanlığında hazırladığ "İşverenlerin Engellilere Yönelik Tutumları ile Engelli Çalışanların Çalışma Alanına Yönelik Görüşlerinin İncelenmesi” başlıklı yüksek lisans tezinden üretilmiştir.

* Sorumlu Yazar. Tel: +90 5077831074 | Araștırma Makalesi.

Makale Tarih Bilgisi. Gönderim: 24.06.2020, Kabûl: 14.12.2020, Erken Görünüm: 20.09.2021, Basım: Haziran, 2022

(C) 2022. Kalem Eğitim ve Sağlık Hizmetleri Vakfı. Bütün Hakları Saklıdır. ISSN: 2146-5606, e-ISSN: 2687-6574.
} 
geçiş sürecine yönelik geçiş dönemi programları düzenlenmesi önerilebilir.

Anahtar Sözcükler: Engelli birey; Engelli çalışan; İstihdam.

\title{
Examining Views of Employees with Disability on Working Areas and on Employers
}

\begin{abstract}
The purpose of this study is to examine views of employees with disabilities (EWDs) on their workplaces and employers. Qualitative research method was used to examine the views of EWDs about their employers. Research sample includes 35 EWDs in 26 businesses, in Selçuklu, Meram and Ereğli districts of Konya Province. Opinions of EWDs were collected with semi-structured interview forms and quantitative-descriptive analyses were performed. By the end of the study, fourteen of the EWDs indicated that their employers, in their approach to problems, performed a fair division of labor, decreased EWDs' workload, provided a learning period and taught EWDs about the job. Although, five of the EWDs mentioned that their employers assigned jobs to them without consulting them and did not perform a fair division of labor; EWDs performed their duties by themselves or their employers assigned them jobs outside of their capabilities, disability types and levels. We may recommend organization of transition programs which aims transition of individuals with disabilities from school to professional life.
\end{abstract}

Keywords: Individual with a disability; Employee with a disability; Employment.

\section{Extended Summary}

\section{Purpose}

People with disabilities (PWDs) usually face various problems before, during and after professional life. During the hiring process, PWDs are turned down for employment because of the prejudices that they don't possess the required qualifications, or they lack abilities required for work (Arslan and Altıntaş, 2014). This study intends to present people with disabilities' (PWDs) competence, adaptations and contributions to the workplace, their expectations from the workplace and their opinions on the employer and the workplace. Results of this study will make determination of current status of PWDs within employment and precautions for improvement easier. In this regard, Aim of this study is examining the opinions of employees with disabilities 
(EWDs) on their workplace and employer.

\section{Method}

Qualitative research method was used to examine the views of EWDs on their employers. Research sample includes 35 EWDs in 26 businesses, in Selçuklu, Meram and Ereğli districts of Konya Province. Opinions of EWDs were collected with semi-structured interview forms and quantitative-descriptive analyses were performed.

\section{Results}

Findings on opinions of EWDs on their workplaces and employers show that required competencies of EWDs vary according to their occupation. EWDs stated that job related skills were the most challenging aspect of their occupation and they were assigned tasks beyond their performance and physical strengths. EWDs recorded that they expect physical regulations, disability sensitivity and positive attitudes from their employers. They also indicated a need to increase the numbers of EWDs and employment of PWDs in public service being addressed through EKPSS and İsKUR. 14 of EWDs (40\%) stated that their employers addressed their issues in a positive approach. 5 of the EWDs (14.25\%) expressed that their employers approached their issues in a negative attitude.

\section{Discussion}

EWDs indicated that a person with disability should be competent in technological knowledge and skill $(\mathrm{n}=13,31.70 \%)$, job skill $(\mathrm{n}=11,26.82 \%)$, communications skills $(\mathrm{n}=9,21.95 \%)$, academic skill $(\mathrm{n}=8,19.51 \%)$ in order to be employed in a workplace. Research shows that employers look for academic skills (Baran and Cavkaytar, 2007), communication, technology and job skills (Güneş and Akçamete, 2014), basic computer, basic literacy and arithmetic skills (MEB, 2013) in EWDs.

EWDs recorded that they were having difficulties in job skills $(n=10$, $25.64 \%)$, physical conditions in their workplaces $(\mathrm{n}=3,7.69 \%)$, disability sensitivity $(\mathrm{n}=2,5.12 \%)$, negative attitudes $(\mathrm{n}=1,2.56 \%)$, communication $(\mathrm{n}=4$, $10.25 \%)$ lack of technological tools $(\mathrm{n}=2,5.12 \%)$ and lack of technological knowledge $(\mathrm{n}=1,2.56 \%)$. Literature shows that EWDs are having problems in physical regulations, negative attitudes of employers (Hasırcığlu, 2006), inadequcies of physical conditions, lack of technological tools and discrimination (Toplu, 2009). On the other hand, Eren's study (2010) found that EWDs 
do not suffer difficulties with their jobs.

20 of the EWDs (57.14\%) indicated that there is no difference in workload between themselves and other employees. 15 of the EWDs (42.85\%) indicated that they had differences in workload between themselves and other employees. Among EWDs who indicated a difference in workload, 10 of them indicated that difference was positive and 5 of them indicated that difference was negative. Related literature on EWDs and employers show that EWDs are employed in simple and non-specialized occupations (Karakuyu, 2017), jobs beyond their capacities (Şahin, 2001; Tören, 2014) or occupations which are light and not especially difficult for their disabilities (Köksal, 2010).

EWDs reported that they usually expect physical regulations $(n=9$, $23.07 \%)$, disability sensitivity $(n=5,12.82 \%)$, positive attitude $(n=6,15.38 \%)$ from their employers. Also, they issued concerns on work hours $(n=3,7.69 \%)$, break hours $(\mathrm{n}=2,5.12 \%)$, break locations $(\mathrm{n}=1,2.56 \%)$ and leaves of absence $(\mathrm{n}=3,7.69 \%)$. Previous research identified expectations from employees as physical regulations (Karakuyu, 2017), equal treatment (Eren, 2010), management of break time (TÜİK, 2002).

EWDs reported opinions on employment of PWDs in regards to employment of PWDs in public service $(n=5,13.15 \%)$, increasing the number of EWDs ( $\mathrm{n}=4,10.52 \%)$, hiring of PWDs through EKPSS ( $\mathrm{n}=9,23.68 \%)$, employment of PWDs through İŞKUR ( $\mathrm{n}=6,15.78 \%)$ and on the job training $(\mathrm{n}=2,5.26 \%)$. Previous research reveals the imporantance of employment of PWDs in public service (Köksal, 2010), founding technical courses for PWDs, making İŞKUR more proactive in employment of PWDs (Orhan, 2013), vocational training, increasing employment of PWDs (Özdemir, 2008) and increasing the number of EWDs (Şahin, 2001).

14 of the EWDs (40\%) indicated that employers displayed positive attitudes to problems. 5 of the EWDs (14.25\%) indicated that employers displayed negative attitudes to problems. Studies reveal that employers have positive attitudes towards work capacity of PWDs (Greenan, Wu and Black, 2002; Aile, Çalışma ve Sosyal Politikalar Bakanlığ1, 2011; Petty and Fussell, 1992). One study in literature towards female EWDs shows findings that female EWDs usually do not experience bad treatment from their supervisors (Tören, 2014). 


\section{Conclusion}

In this study, fourteen of the EWDs indicated that their employers provided a fair division of labor, decreased their workloads, provided a learning period and personally trained employees. Five of the EWDs indicated that their employers assigned tasks to them without consultation, did not do a fair division of labor, that they were working alone or their employers assigned tasks which are outside of employees' capabilities, type of disability and levels. These recommendations could be made in regards of findings of this study: Seminars and in service training programs can be organized in order to increase the awareness of employers on tasks that can be performed by EWDs, their occupational skills and abilities, their productivity in workforce and their performance. Transition programs in regard to transition from school to occupation can be organized and these programs can be supported with legal regulations and cooperation among institutions can be supported.

\section{Giriş}

Alanyazında engelli kavramı; bir yetersizlik veya özür nedeni ile gelişim düzeyine, cinsiyet özelliklerine, sosyal faktörlere bağlı olarak bireyden beklenen rollerin gerçekleştirilememesi olarak yer almaktadır (Çarkçı, 2011). Özellikle sanayi devriminden sonra engellilik kavramı, sosyal hayatta eskiye göre daha fazla kullanılmaya başlanmıştır. Sanayi devriminden sonra bireylerin doğuştan getirdiği engelliliğin yanı sıra çalışma koşulları nedeniyle iş kazaları sonucunda engellilik sayısında artış meydana gelmiştir (Çarkçı, 2011). Toplumsal hayat, teknoloji ve sanayi alanında meydana gelen gelişmeler neticesinde sosyal ortamdan geri kalarak evlerine kapanan engellilerin, toplumla etkileşim hâlinde olmaları yönünde talepler oluşmaya başlamıştır (Genç ve Çat, 2013). Bu gelişmelerin ardından engelliler ile ilgili uluslararası ve ulusal çapta yasal düzenlemelerin oluşturulması zorunlu hâle gelmiştir (Çarkçı, 2011; Gökmen, 2007).

Engellilerin istihdamına yönelik Birleşmiş Milletler Genel Kurulu kararı ile ilk kez 20.12.1983 tarihli 48/96 sayılı "Sakatlar İçin Fırsat Eşitliği Konusunda Standart Kurallar" kabul edilmiştir. Sakatlar İçin Fırsat Eşitliği Konusunda Standart Kurallar'da, engellilerin istihdamını zorlaştıran yaklaşımların ve yasaların olmaması gerektiği açıkça belirtilmiştir (Kurt, 2020).

Devletlerin kamu sektöründe engelli istihdamına destek vermesi yönünde düzenlemelere gitmesini, özel sektörlerin, engellilerin istihdamına yönelik eğitimler ve iş hayatına atılmaları konusunda kolaylaştırıcı önlemler 
almaları konusunda kararlar alınmıştır. 13 Aralık 2006 tarihinde Birleşmiş Milletler Genel Kurulu tarafından Engelli Kişilerin Hakları Sözleşmesi kabul edilerek 82 ülkenin onayı ile 03.05.2008 tarihinde yürürlüğe girmiştir (Aile, Çalışma ve Sosyal Politikalar Bakanlığı, 2015). Bu sözleşmeyi onaylayan ülkeler arasında Türkiye de yer almaktadır.

Dünyada engelli bireylere yönelik yapılan düzenlemeler ile ülkemizde de engellilere yönelik istihdam 1980 yılından itibaren hızlanmıştır. Engelli bireylerin istihdamını sağlamaya yönelik, kota yöntemi ile ilgili düzenlemeler yapılmıştır. Birleşmiş Milletler'in 1981 yılını "Uluslararası Özürlüler Yılı" ilan etmesinin ardından, 1983 yılından itibaren "Dünya Özürlüler 10 Y1lı" olarak kabul etmesi, Türkiye'de de bazı çalışmaların hız kazanmasına neden olmuştur. (Gökmen, 2007). 1982'de yürürlüğe konulan Türkiye Cumhuriyeti Anayasasında "Herkes, dil, ırk, renk, cinsiyet, siyasi düşünce, felsefi inanç, din, mezhep ve benzeri sebeplerle ayrım gözetmeksizin kanun önünde eşittir." hükmü ile özürlü kişilerin hakları güvence altına alınmıştır (Gökmen, 2007). Ülkemizde, 1990'lı yılların ikinci yarısından itibaren engellilere yönelik uygulamalar için politika belirleme, yasal mevzuatı ve kurumsal yapıyı oluşturma faaliyetleri artmıştır. 1997 yılında Özürlüler İdaresi Başkanlığı'nın kurulması, 1999 yılında ilk "Özürlüler Şûrası"nın toplanması ve 2005 yılında kısaca "Özürlüler Kanunu" olarak bilinen yasal düzenlemenin yapılması engellilere yönelik politikalardaki yoğunlaşmanın temel göstergeleridir (Özgökçeler ve Alper, 2010).

Ülkemizde yaşanan yasal gelişmelerin yanı sıra akademik gelişmelerde de engelli işveren, çalışan ve istihdamı ile alakalı engelli çalışmalara rastlanmaktadır (Baran ve Cavkaytar, 2007; Eren, 2010; Hasırcıŏlu, 2006; Köksal, 2010; Orhan, 2013; Şahin, 2001; Toplu, 2009; Tören, 2014). Öztürk (2011)'ün yaptığ 1 çalışmada, engelli istihdamının işverenler tarafından bir yük olarak algılandığ 1 görülmektedir. İşverenler iş piyasasındaki rekabet ortamında verimli istihdamı gerçekleştirmek zorunda olduklarını ancak istihdam içerisinde yer alan engelli bireylere çalışma ortamında uygun iş bulmakta zorlandıklarını, engelli bireylerin iş ortamında verimli olmadıklarını belirtmişlerdir. Çalışan engelli bireyler ile yapılan bir çalışmada ise çalıştığ işin kişinin yeterliliklerine uygun olmadığı, işin gerektirdiği nitelikleri taşımadığı önyargıları sebebiyle çalışma arkadaşları ve işverenler tarafından olumsuz tutum ve davranışlarla karşılaştıkları sonuçları elde edilmiştir (Arslan ve Altıntaş, 2014).

Genel olarak engelli bireyler iş hayatının öncesi, iş hayatı süresince ve 
sonrası birçok problem ile karşılaşmaktadır. Engelli bireyler işe yerleştirme sürecinde işe alınacak bireylerde aranan niteliklere sahip olamamaları ya da işi yapabilme özelliğinden yoksun olduklarına yönelik önyargılar sebebiyle bir iş sahibi olamamaktadır (Arslan ve Altıntaş, 2014). Yapılan bu çalışma engelli bireylerin yeterlilikleri, iş yerine olan uyumları ve bu bireylerin kuruma yaptıkları katkıları, iş yerinden beklentileri, işveren ve iş yerine yönelik düşüncelerini ortaya koymayı amaçlamaktadır. Bu bağlamda çalışmanın sonuçları çalışma hayatında yer alan engelli çalışanlar açısından istihdamdaki mevcut durumun ve iyileştirme tedbirlerinin belirlenmesini kolaylaştıracaktır. $\mathrm{Bu}$ bağlamda araştırmanın amacı; engelli çalışanların iş yeri ve işverene yönelik görüşlerinin neler olduğunu belirlemektir. $\mathrm{Bu}$ amaç doğrultusunda şu sorulara cevap aranmıştır:

1. Bir iş yerinde çalışan ya da çalışacak olan engelli bireyin sahip olması gereken yeterlilikler nelerdir?

2. Engelli çalışanlar iş yerinde hangi beceri alanına ilişkin yeterliliklerde zorlanmaktadir?

3. Engelli bireyler, iş yerinde kendine verilen işlerle diğer bireylere verilen işler arasında ne gibi farklıklar olduğunu düşünmektedir?

4. Engelli çalışanların çalıştıkları iş yerindeki işverenden beklentileri nelerdir?

5. Engelli çalışanlar, engelli bireylerin istihdam edilme şekli hakkında ne düşünmektedir?

6. Engelli çalışanların iş yerinde zorlandıkları alanlarda işveren nasıl yardımcı olmaktadır?

\section{Araştırma Modeli}

\section{Yöntem}

$\mathrm{Bu}$ araştırmada nitel araştırma yöntemi kullanılmıştır. Gözlem, görüşme ve doküman analizi gibi nitel veri toplama yöntemlerinin kullanıldığı, olayların ve algıların doğal ortamda bütüncül ve gerçekçi bir biçimde ortaya konmasına yönelik nitel bir sürecin izlendiği araştırmaya nitel araştırma denir (Yıldırım ve Şimşek, 2013). Çalışmada veriler yarı yapılandırılmış görüşme yöntemi ile elde edilmiştir.

\section{Çalışma Grubu}

Çalışma grubu, engelli çalışanların işveren ve iş yerine yönelik görüşlerinin neler olduğu amacından yola çıkarak amaçlı örnekleme yöntemi ile belirlenmiştir. Amaçlı örnekleme, araştırmanın amaçları dikkate alınarak bir 
evreni temsil eden bir örneği yerine amaçlı olarak bir ya da birkaç alt kesimi örnek olarak belirlemektir. Evrenin problemine en uygun kesimi gözlem konusu olarak ele almak olarak da ifade edilebilir (Yıldırım ve Şimşek, 2013).

Tablo 1. Engelli Çalışanların Kișisel Bilgileri

\begin{tabular}{|c|c|c|c|}
\hline & & $\begin{array}{l}\text { Frekans } \\
\text { (f) }\end{array}$ & $\begin{array}{l}\text { Yüzdelik } \\
(\%)\end{array}$ \\
\hline \multirow[t]{2}{*}{ Cinsiyet } & Kadın & 7 & 20.00 \\
\hline & Erkek & 28 & 80.00 \\
\hline \multirow[t]{2}{*}{ Kurum } & Özel & 21 & 60.00 \\
\hline & Devlet & 14 & 40,00 \\
\hline \multirow[t]{4}{*}{ Eğitim } & İlkokul & 5 & 14.28 \\
\hline & Ortaokul & 8 & 22.85 \\
\hline & Lise & 12 & 34.28 \\
\hline & Üniversite & 10 & 28.57 \\
\hline \multirow[t]{5}{*}{ Engel Türü } & Zihinsel Engelli & 8 & 22.85 \\
\hline & Görme Engelli & 8 & 22.85 \\
\hline & İşitme Engelli & 4 & 11.42 \\
\hline & Ortopedik Engelli & 11 & 31.42 \\
\hline & Süreğen Rahatsızlık & 4 & 11.42 \\
\hline \multirow[t]{5}{*}{ Sektör } & G1da & 6 & 17.14 \\
\hline & Toplumsal ve Kişisel Hizmet & 12 & 34.28 \\
\hline & Tarım & 5 & 14.28 \\
\hline & Turizm Konaklama Yiyecek İçecek Hizmetleri & 8 & 22.85 \\
\hline & Satış ve Pazarlama & 4 & 11.42 \\
\hline \multirow[t]{4}{*}{ İşe Girme Şekli } & İşkur & 7 & 20.00 \\
\hline & Ekpss & 4 & 11.42 \\
\hline & Bireysel Başvuru & 16 & 45.71 \\
\hline & Kurum Sinavi & 8 & 22.85 \\
\hline Meslekte & $0-5$ Y1l & 20 & 57.14 \\
\hline \multirow[t]{3}{*}{ Çalışma Süresi } & 6-10 Y1l & 2 & 5.71 \\
\hline & $11-15 Y_{11}$ & 7 & 20.00 \\
\hline & 16 Y1l ve Üstü & 6 & 17.14 \\
\hline Meslekî Eğitim & Evet & 14 & 40.00 \\
\hline Kursu Alma & Hayır & 21 & 60.00 \\
\hline
\end{tabular}

Araştırma grubunu Konya ili merkez ilçeleri Meram, Selçuklu ve Ereğli ilçesinde yer alan kamu sektöründe ve özel işletmelerde çalışan 35 engelli birey oluşturmaktadır. Araştırmaya katılan engelli bireylerin 28'i erkek, 7'si kadındır. Engelli çalışanların 21'i devlet, 14'ü özel sektörde çalışmaktadır. Araştırmaya katılan 35 engelli çalışandan 10'u üniversite, 12'si lise, 8'i ortaokul, 5'i ilkokul mezunudur. Engelli çalışanların 6's1 gıda, 12'si toplumsal ve kişisel hizmet, 5'i tarım, 8'i turizm konaklama yiyecek içecek hizmetleri, 4'ü satış ve pazarlama sektöründe çalışmaktadır. Engelli çalışanların 11'i ortopedik 
engelli, 8'i görme engelli, 4'ü süreğen rahatsılılı, 8'i zihinsel engelli, 4'ü işitme engellidir. Araştırmaya katılan engelli çalışanların 16'sı bireysel başvuru, 8'i kurum sınavı, 7'si İŞKUR, 4'ü EKPSS ile işe yerleşenlerden oluşmaktadır. Engelli çalışanlardan hizmet içi eğitim alanlar 14, hizmet içi eğitim almayanlar ise 21 kişidir.

\section{Veri Toplama Araçları}

Engelli çalışanların iş yeri ve işverene yönelik görüşlerinin elde edilmesi amacıyla "Yarı Yapılandırılmış Görüşme Formu" hazırlanmıştır. Görüşme formu iki bölümden oluşmaktadır. İlk bölümde engelli çalışanların kişisel bilgilerini toplamaya yönelik sorular yer almaktadır. İkinci bölümde ise engelli çalışanların iş yeri ve işverenine yönelik sorulara yer verilmiştir. Görüşme formundaki sorular Güneş ve Akçamete (2014), Mamatoğlu, Dökmen ve Yıldırım (2015), Baran ve Cavkaytar'ın (2007) yapmış oldukları araştırmadaki görüşme sorularından yararlanılarak hazırlanmıştır. Alanyazındaki çalışmalarda yer alan görüşme sorularından araştırmanın amacına uygun olduğu düşünülen sorular belirlenmiş, ifadelerde uyarlamalar yapılarak görüşme formu oluşturulmuştur. Oluşturulan görüşme soruları alanda uzman 3 öğretim elemanının görüşüne sunularak araştırmanın amacına uygun olup olmadığ1 belirlenmeye çalışılmıştır. Uzmanların önerileri doğrultusunda yapılan inceleme sonucunda herhangi bir değişiklik yapılmadan sorulara son şekli verilmiştir.

Oluşturulan bu form için pilot uygulama bölgesi belirlenmiş ve gerekli izinler alınarak 35 engelli çalışana uygulanmıştır. Görüşmeler uygulamaya dâhil olan her engelli çalışanın iş yerine gidilerek yapılmıştır. Görüşmelerde işveren tarafindan belirlenen yalnız uygulayıcı ile engelli çalışanın olduğu ortamda yüz yüze ve ses kayıt cihazı ile yapılmıştır. Pilot uygulama ile soruların araştırmanın amacına uygun olduğu sonucuna ulaşı1mıştır. Pilot uygulamada kullanılan görüşme formundaki 7 soru herhangi bir düzenleme yapılmadan bu araştırmada engelli çalışanların iş yeri ve işverenine yönelik görüşlerini almak için kullanılmıştır.

\section{Verilerin Toplanması ve Analizi}

Verilerin toplanmasında araştırma yapılacak engelli çalışanlar ve iş yerlerinin belirlenmesinden sonra araştırmacı, işyerlerine telefon ederek işverenler ve engelli çalışanlar ile görüşmüştür. Telefon görüşmelerinde araştırmacı kendini tanıtarak araştırmanın amacı açıklamıştır. Yapılacak olan görüşmede, engelli çalışanlara "engelli çalışanların iş yeri ve işverenine yönelik 
görüşlerini belirlemek amacıyla bir görüşme formu uygulayacağını bunun için ses kaydı yapılacağını belirtmiş ve araştırmaya katılıp katılmayacaklarını" sormuştur. Araştırmaya gönüllü olarak katılmayı kabul eden engelli çalışanlardan onlara uygun bir zaman için randevu alınmıştır. Randevu zamanında uygulamaya dâhil olan her engelli çalışanın iş yerine şahsen gidilerek işveren/işveren yetkilisine gerekli açıklamalar yapıldıktan sonra engelli çalışanlarla görüşme yapılmıştır. Görüşmeler iş yerinde işveren tarafindan belirlenen yalnız uygulayıcı ile engelli çalışanın olduğu bir ortamda engelli çalışana gerekli açıklamalar yapıldıktan sonra yüz yüze ve ses kayıt cihazı kullanılarak yapılmıştır.

Araştırmada elde edilen veriler betimsel analiz yaklaşımına göre analiz edilmiştir. Betimsel analizde, gözlenen ya da görüşülen bireylerin görüşlerini etkili bir biçimde aktarmak amacıyla doğrudan alıntılara sık sık yer verilir. $\mathrm{Bu}$ tür analizde amaç elde edilen bulguları düzenlenmiş ve yorumlanmış olarak okuyucuya aktarmaktır (Yıldırım ve Şimşek, 2013). Verilerin analizinde ses kayıt cihazıyla kayıt altına alınıp yazılı hâle getirilen görüşmelerin tamamı tek tek okunarak her bir soru maddesinde yer alan yanıtlardan "Görüşme Kodlama Anahtarı" oluşsturulmuştur. Görüşme kodlama anahtarındaki kategorilerin uygunluğuna yönelik olarak her bir görüşme için boş görüşme kodlama anahtarı yapılmıştır. 3 görüşme tesadüfî olarak seçilerek bir uzman ve araştırmacı tarafından birbirinden bağımsız olarak görüşme kodlama anahtarına göre değerlendirilmiştir. Araştırmacı ve uzmanın yaptığı bu işaretlemeleri tutarlılığına yönelik görüşme kodlama anahtarındaki her bir sorunun cevabı tek tek karş1laştırılarak gerekli görülen değişiklikler yapılarak görüşme kodlama anahtarına son şekli oluşturulmuştur. İçerikte belirlenmiş maddelerin tekrar etme sıklığı frekans ve yüzde verilerine yer verilmiştir. Çalışmanın güvenirliğinin sağlanması için engelli çalışanların görüşlerinden doğrudan alıntılara yer verilmiştir.

\section{Bulgular}

$\mathrm{Bu}$ bölümde görüşmeye katılan engelli çalışanların iş yeri ve işverenlerine ilişkin görüşleri; engellilerin iş hayatı, engelli çalışanların işverenden beklentileri, engelli istihdamı, işverenlerin iş yerindeki uygulamaları olmak üzere dört tema altında toplanmıştır. Bu temalara ilişkin bilgiler yer almaktadır. Aşağıda engelli çalışanların iş yeri ve işverenine ait görüşlerine ilişkin veriler temalar hâlinde verilmiştir. 


\section{Engelli Çalışanların İş Hayatı}

$\mathrm{Bu}$ tema altında engelli çalışanların görüşleri; çalışma alanında sahip olunması gereken yeterlilikler, işte yaşanılan güçlükler ve iş yerindeki iş dağılımına yönelik görüşler olmak üzere üç alt tema altında sunulmaktadır.

\section{Çalışma Alanında Sahip Olunması Gereken Yeterlilikler}

Engelli çalışanların çalıştıkları iş yerindeki çalışan ya da çalışacak olan engelli bireyin sahip olması gereken yeterliliklerin neler olduğuna yönelik görüşleri incelendiğinde, teknoloji bilgi ve becerisi 13 (\%31.70), iş becerisi 11 (\%26.82), iletişim becerisi 9 (\%21.95), akademik beceri 8 (\%19.51) konularını ifade ettikleri belirlenmiştir. Engelli çalışanlar bir iş yerinde çalışacak engelli bireyin en çok teknolojisi bilgi ve becerisi ile iş becerisine sahip olması gerektiği yönünde görüş belirtmişlerdir. Aşağıda bu duruma ilişkin engelli çalışanların görüşlerinden kesitlere yer verilmiştir:

"Bu işi yapabilmesi için temel web tasarımı, Office, Excel gibi bilgisayar programlariyla ilgili bilgi sahibi olmalı ve bu programları kullanabilmelidir." (Engelli Çalı̧̧an 37).

"IŞs ve günlük hayatın sürdürürken karşılaştı̆̆ insanlarla pozitif iletişim içerisinde olmalı ve diksiyonun düzgün olması gerekir. Bu noktalara dikkat edildiğinde birçok şey kolaylaşmış oluyor." (Engelli Çalışan 10).

\section{İşte Yaşanılan Güçlükler}

Engelli çalışanların iş yerinde zorlandıkları yeterliliklere yönelik görüşleri incelendiğinde iş becerisi 10 (\%25.64), fizikî koşullar 3 (\%7.69), engelli duyarlılığı 2 (\%5.12), olumsuz tutum 1 (\%2.56), iletişim 4 (\%10.25), teknolojik cihazların eksikliği 2 (\%5.12), teknolojik bilgi eksikliği 1 (\%2.56) konularında zorlandıklarını ifade etmişlerdir. Engelli çalışanlar en çok iş becerilerinde zorlandıkları, performansının ve beden gücünün üstünde işler verildiği yönünde görüş belirtmişlerdir. Çalışmaya katılan engelli çalışanların 16's1 (\%41.02) iş yerinde bir güçlük yaşamadıklarını söylemişlerdir. Bu duruma ilişkin engelli çalışanların görüşleri şöyledir: "İşyerinde koli kaldırma, koliyi çekmede ve ürünlerin taşınmasında zorlanıyorum. Bu işi yapabilmek için gücünün olması gerekiyor. Başka bir alanda zorlanmıyorum." (Engelli Çalışan 19), "Herhangi bir zorlanma yaşamadım. 17 yıldır hiçbir şey yaşamadım." (Engelli Çalışan 7).

\section{İşyerindeki İş Dağılımı}

Engelli çalışanların iş yerinde kendilerine verilen işlerle diğer bireylere verilen işler arasındaki farklıklara ilişkin görüşleri incelendiğinde 20'si 
(\%57.14) kendileriyle ile diğer çalışanlar arasında iş farklılığı olmadığını belirtmişlerdir. Engelli çalışanların 15'i (\%42.85) kendileriyle ile diğer çalışanlar arasında iş farklılığ olduğunu ifade etmişlerdir. İş farklılığ olduğunu ifade eden engelli çalışanların 10'u işteki farklılığı olumlu anlamda ifade ederken 5 engelli çalışan işteki farklılığı olumsuz olarak belirtmiştir. İşteki farklılığ olumsuz olarak ifade eden engelli çalışanlar, işverenlerin verilen işlerde engellilerin görüşünü ve yeterliliklerini dikkate almadıklarını ve genellikle kendilerini geri hizmet pozisyonundaki görevlere verdiklerini ifade etmişlerdir. İşteki farkl1lığın olumlu olduğunu belirten engelli çalışanlar işverenlerin kendi engellerine uygun kolay ve hafif işler verdiklerini belirtmişlerdir. Bu duruma ilişkin engelli çalışanların görüşlerinden kesitler şöyledir: "Raporum olduğu için diğer çalışanların yaptı̆̆ getir-götür işlerini yapmıyorum. Genellikle oturarak yapılan hafif işler veriliyor." (Engelli Çalışan 7), "İş yeri paketleme işi üzerine olduğu için diğer çalışanlarla aynı işi yapıyoruz." (Engelli Çalışan 28).

\section{Engelli Çalışanın İşverenden Beklentileri}

Engelli çalışanların çalıştıkları iş yerindeki işverenden beklentilerine yönelik görüşleri incelendiğinde çoğunlukla fizikî düzenleme 9 (\%23.07), engelli duyarlılığ 5 (12.82), olumlu tutum 6 (\%15.38) konularını ifade ettikleri belirlenmiştir. Ayrıca çalışma saati 3 (\%7.69), dinlenme saati 2 (\%5.12), dinlenme ortamı 1 (\%2.56) ve izin $3(\% 7.69)$ konularını belirtmişlerdir. Engelli çalışanların 10'u (\%25.64) işvereninden herhangi bir beklentileri olmadığını ifade etmişlerdir. Bu duruma ilişkin engelli çalışanların görüşlerinden kesitler şöyledir: "Ortopedik engelime yönelik olarak rampa ve kendi başıma iş yerine girebilmek ve iş yerinde dolaşmak için düz bir zemin olmall. Bu mümkün değilse asansör yaptırılmalı.” (Engelli Çalışan 17), “Engelli olarak değer verilip ifade ettiklerim dikkate alınarak ihtiyaçlarımın karşılanması gerektiğini düşünüyorum.” (Engelli Çalışan 8).

\section{Engelli İstihdamı}

Engelli çalışanların engelli bireylerin istihdam edilme şekli hakkında görüşleri incelendiğinde engelli istihdamı konusundaki görüşlerini de ifade ettikleri görülmektedir. Engelli çalışanlar, kamuda engelli istihdamı 5 (\%13.15), engelli çalışan sayısının artırılması 4, (\%10.52) EKPSS ile engelli istihdamı 9 (23.68), İŞKUR aracıllı̆ı̆yla engelli istihdamı 6 (\%15.78) ve hizmet içi eğitim 2 (\%5.26) konularında görüş belirtmişlerdir. Ağırlıklı olarak engelli çalışan sayısı, EKPSS ve İŞKUR aracılığı ile engelli istihdamı ve kamuda engelli 
istihdamı konularını ifade ettikleri görülmektedir. Engelli çalışanların 9'u (\%23.68), engelli istihdam şekli ilgili bir fikir sahibi olmadıklarını ifade etmiştir. Engelli çalışanların 3'ü (\%7.89), herhangi bir görüş belirtmemiştir. Bu duruma ilişkin engelli çalışanların görüşlerinden kesitler şöyledir: "Engelli istihdamı açısından şu anki EKPSS sistemini, sinavdaki puanın dikkate alınıp hakkın ve adaletin sağlanarak yerleştirmenin yapıldĭ̆ adil bir sistem olarak düşünüyorum." (Engelli Çalışan 10), "Engellilerin maddi anlamda ve sağllk yönünden ihtiyaçları dikkate alındığında diğer insanlara göre daha fazla istihdam edilmesi gerektiğini düşünüyorum.” (Engelli Çalışan 7).

\section{İşverenlerinin İş Yerindeki Uygulamaları}

İşverenin iş yerindeki uygulamalarına yönelik görüşleri işverenin sorunlara yaklaşımı teması altında sunulmaktadır.

\section{İşverenin Sorunlara Yaklaşımı}

Engelli çalışanların zorlandıkları alanlarda işverenin nasıl yardımcı olduğuna yönelik görüşleri incelendiğinde engelli çalışanların 14'ü (\%40) işverenlerin sorunlara karşı olumlu yaklaşım sergilediklerini belirtmişlerdir. İşverenlerin sorunlarla ilgili olarak görev paylaşımı yaptıklarını, iş yükünü azalttıklarını, öğrenme suresi tanıdıklarını, işin öğretimini yaptıklarını ifade etmişlerdir. Engelli çalışanların 5'i (\%14.28) işverenlerin sorunlara karşı olumsuz bir yaklaşım içerisinde olduklarını belirtmişlerdir. İşverenlerin sorunlara olumsuz yaklaşımı ile ilgili olarak işleri tek başına yaptıklarını ya da işverenlerin, kendilerinin sahip olduğu yeterlilikler, engel turu ve seviyeleri dişında işler verdiklerini dile getirmişlerdir. Engelli çalışanların 16's1 (\%45.71) iş yerinde sorun olmadığ 1 için görüş belirtmemişlerdir. Bu duruma ilişkin engelli çalışanların görüşlerinden kesitler şöyledir: "İ̧̧verenim bana karşı sabırlı davranarak işi ögrenmem için firsatlar tanıdı. Böylelikle iş ortamına alıştım." (Engelli Çalışan 17), "İ̧yerinde verilen işte işveren yardımcı olmuyor, işi tek başıma yapıyorum.” (Engelli Çalışan 19).

Engelli çalışanların iş yeri ve iş yerine yönelik görüşlerine ilişkin bulgular değerlendirildiğinde sonuç olarak; iş hayatındaki engellilerin sahip olması gereken yeterliliklerin çalıştıkları işe göre değiştiği görülmektedir. Engelli çalışanlar iş yerinde en çok iş becerilerinde zorlandıklarını, performansının ve beden gücünün üstünde işler verildiğini belirtmişlerdir. 16 engelli çal1şan iş yerinde herhangi bir güçlük yaşamadıklarını ifade etmişlerdir. Kendileri ile ve diğer çalışanlar arasında iş farklılığı olduğunu ifade eden engelli çal1şanların 10'u işteki farklılığı olumlu anlamda ifade ederken 5 engelli çalışan 
işteki farklılığı olumsuz olarak belirtmiştir. İşte ki farklılığın olumlu olduğunu belirten engelli çalışanlar işverenlerin engeline uygun kolay ve hafif işler verdiklerini ifade etmişlerdir. Engelli çalışanlar işverenden beklentilerinde çoğunlukla fizikî düzenleme, engelli duyarlılığ1, olumlu tutum konularında görüş belirtmişlerdir. 10 engelli çalışan ise işvereninden herhangi bir beklentileri olmadığını ifade etmiştir. Engelli istihdamı ile ilgili ağırlıklı olarak engelli çalışan sayısının artırılması, EKPSS ve İŞKUR aracılığ 1 ile engelli istihdamı ve kamuda engelli istihdamı konularına ağırlık verilmesi gerektiğini belirtmişlerdir. Engelli çalışanların 14'ü (\%40) işverenlerin sorunlara karşı olumlu yaklaşım sergilediklerini belirtmişlerdir. 5 (\%14.28) engelli çalışan ise işverenlerin sorunlara karşı olumsuz bir yaklaşım içerisinde olduklarını belirtmişlerdir.

\section{Tartışma ve Sonuç}

$\mathrm{Bu}$ bölümde engelli çalışanların işveren ve iş yerine görüşlerine ilişkin bulgular; engelli çalışanların çalışma alanında sahip olması gereken yeterlilikler, işte yaşanılan güçlükler, iş yerindeki iş dağılımı, engelli çalışanın işverenden beklentileri, engelli istihdamı, işverenin sorunlara yaklaşımı çerçevesinde alanyazınla desteklenerek tartışılmıştır.

Engelli çalışanların çalıştıkları iş yerindeki çalışan ya da çalışacak olan engelli bireyin sahip olması gereken yeterliliklerin neler olduğuna yönelik görüşleri incelendiğinde, teknoloji bilgi ve becerisi (13, \%31.70), iş becerisi (11, $\% 26.82)$, iletişim becerisi (9, \%21.95), akademik beceri (8, \%19.51) konularını ifade ettikleri belirlenmiştir. Alanyazındaki araştırmalar, engelli çalışanların bir iş yerinde çalışabilmesi için sahip olması gereken yeterliliklere değinmişlerdir. Araştırmalarda işverenlerin engelli çalışanlarda akademik işlem (Baran ve Cavkaytar, 2007), iletişim, teknoloji, iş becerileri (Güneş ve Akçamete, 2014), temel bilgisayar, temel okuma-yazma ve aritmetik becerileri (Milli Eğitim Bakanlığı, 2013) aradıkları görülmektedir.

Engelli çalışanların iş yerinde zorlandıkları yeterliliklere yönelik görüşleri incelendiğinde engelli çalışanlar; iş becerisi (10, \%25.64), fizikî koşullar (3, \%7.69), engelli duyarlılı̆g $(2, \% 5.12)$, olumsuz tutum (1, \%2.56), iletişim (4, \%10.25), teknolojik cihazların eksikliği (2, \%5.12), teknolojik bilgi eksikliği (1, \%2.56) konularında zorlandıkları yönünde görüş belirtmişlerdir. Çalışmaya katılan engelli çalışanların 16'sı (\%41.02) iş yerinde bir güçlük yaşadıklarını söylemişlerdir. Araştırmalarda engelli çalışanların fizikî düzenleme, işveren olumsuz tutumları (Hasırcıoğlu, 2006), fizikî koşulların yetersizliği, teknolojik cihazların eksikliği, ayrımcılık (Toplu, 2009) konularında problem 
yaşadıkları bulguları yer almaktadır. Ayrıca Eren (2010) araştırmasında engelli çalışanların çalıştıkları işte zorlanmadıkları bulgusunu ortaya koymuştur.

Engelli çalışanların iş yerinde kendilerine verilen işlerle diğer bireylere verilen işler arasındaki farklılıklara ilişkin görüşleri incelendiğinde 20'sinin (\%57.14) kendileriyle ile diğer çalışanlar arasında iş farklılığı olmadığını belirtmişlerdir. Engelli çalışanların 15'i (\%42.85) kendileriyle ile diğer çalışanlar arasında iş farklılığı olduğunu ifade etmişlerdir. İş farklılığı olduğunu ifade eden engelli çalışanların 10'u işteki farklılığı olumlu anlamda ifade ederken 5 engelli çalışan işteki farklılığ olumsuz olarak belirtmiştir. İ̧̧yerlerindeki farklılığ1 olumsuz olarak ifade eden engelli çalışanlar, işverenlerin verilen işlerde engellilerin görüşünü ve yeterliliklerini dikkate almadıklarını ve genellikle kendilerini geri hizmet pozisyonundaki görevlere verdiklerini ifade etmişlerdir. İşyerlerindeki farklılığın olumlu olduğunu belirten engelli çalışan işverenlerin kendi engellerine uygun kolay ve hafif işler verdiklerini belirtmişlerdir. Alanyazındaki engelli çalışanlar ve işverenlere yönelik yapılan araştırmalarda engelli çalışanların basit ve uzmanlık gerektirmeyen (Karakuyu, 2017), kapasitelerinin üstünde (Şahin, 2001; Tören, 2014) ya da hafif, engelini zorlamayacak işlerde yer aldıkları (Köksal, 2010) bulguları yer almaktadır.

Engelli çalışanların çalıştıkları iş yerindeki işverenden beklentilerine yönelik görüşleri incelendiğinde çoğunlukla fizikî düzenleme (9,\%23.07), engelli duyarlılığ $(5,12.82)$, olumlu tutum $(6, \% 15.38)$ konularını ifade ettikleri belirlenmiştir. Ayrıca çalışma saati (3, \%7.69), dinlenme saati (2, \%5.12), dinlenme ortamı (1, \%2.56) ve izin (3, \%7.69) konularını belirtmişlerdir. Engelli çalışanların 10’u (\%25.64) işvereninden herhangi bir beklentileri olmadığın ifade etmişlerdir. Araştırmalarda işverenden beklentilere ilişkin genellikle fizikî düzenleme (Karakuyu, 2017) eşit davranma, (Eren, 2010) dinlenme zamanı kullanma (Devlet İstatistik Enstitüsü Başkanlığı, 2002) bulguları yer almaktadır.

Engelli çalışanların engelli bireylerin istihdam edilme şekli hakkında görüşleri incelendiğinde engelli istihdamı konusunda görüşlerini ifade etmişlerdir. Engelli çalışanlar, kamuda engelli istihdamı (5, \%13.15), engelli çal1şan sayısının artırılması (4, \%10.52), EKPSS ile engelli istihdamı (9, \%23.68), İŞKUR aracılığıyla engelli istihdamı $(6, \% 15.78)$ ve hizmet içi eğitim (2, \%5.26) konularında görüş belirtmişlerdir. Engelli çalışanların 9'u (\%23.68) engelli istihdam şekli ilgili bir fikir sahibi olmadıklarını ifade etmiş̧tir. Araştırmalarda kamuda engelli istihdamı (Köksal, 2010), engellilerle ilgili meslekî 
kursların açılması, İş-Kur'un özürlü istihdamı konusunda daha aktif olması (Orhan, 2013), meslekî eğitim, engelli istihdamının artırılması (Özdemir, 2008), engelli istihdam sayısının artırılması (Şahin, 2001) bulguları yer almaktadır.

Araştırmada 14 (\%40) engelli çalışan işverenlerin sorunlara yaklaşımı konusunda, işverenlerin işlerle ilgili olarak görev paylaşımı yaptıklarını, iş yükünü azalttıklarını, öğrenme suresi tanıdıklarını, işin öğretimini yaptıklarını ifade etmişlerdir. 5 (\%14.28) engelli çalışan ise işverenlerin iş yerinde kendilerine sormadan işler verdikleri, görev dağılımında âdil davranmadıklarını, işleri tek başına yaptıklarını ya da işverenlerin, kendilerinin sahip olduğu yeterlilikler, engel türü ve seviyeleri dışında işler verdiklerini dile getirmişlerdir. Alanyazında işverenin engelli çalışana yönelik yaklaşım ve tutumunu incelenen araştırmaların genellikle işverenler ile yapıldığ 1 görülmektedir. Araştırmalarda işverenlerin engelli bireylerin iş görebilme düzeyleri ile ilgili olarak olumlu tutuma sahip olduklarını görülür (Aile Çalışma ve Sosyal Politikalar Bakanlığı, 2011; Greenan, Wu ve Black, 2002; Petty ve Fussell, 1992). Ayrıca alanyazında engelli kadın çalışanlara yönelik yapılan bir araştırmada çalışan engelli kadınların genelinin üstleriyle ilgili olarak kötü bir muameleye maruz kalmadıkları (Tören, 2014) bulguları yer almaktadır. Araştırma sonuçları doğrultusunda şu önerilerde bulunulabilir: Engelli çalışanların yapabileceği işler, meslekî beceri ve yetenekleri hakkında işverenlere hizmet içi eğitim programları düzenlenmelidir. Engelli bireyler için eğitim hayatından iş hayatına geçiş̧ sürecini kolaylaştırmaya yönelik geçiş hizmetleri programları düzenlenmelidir. Ayrıca geçiş hizmetleri programları yasal düzenlemeler yapılarak kurumlar arası iş birliği sağlanmalıdır.

\section{Kaynakça}

Aile, Çalışma ve Sosyal Politikalar Bakanlığı. (2011). İşgücü piyasasının özürlüler açısından analizi. Engelli ve Yaşlı Hizmetleri Genel Müdürlüğü Yayınları. https://ailevecalisma.gov.tr/media/5816/isgucu-tam-metin-turkce.pdf.

Aile, Çalışma ve Sosyal Politikalar Bakanlığı. (2015). Kamuda engelli istihdamının analizi. Engelli ve Yaşlı Hizmetleri Genel Müdürlüğü Yayınları.

https://www.ailevecalisma.gov.tr/media/5649/kamuda-engelli-istihdamininanalizi-son.pdf

Anıl, A. (2019). İşverenlerin engellilere yönelik tutumları ile engelli çalışanların çalışma alanına yönelik görüşlerinin incelenmesi. Yayımlanmamış yüksek lisans tezi, Necmettin Erbakan Üniversitesi Eğitim Bilimleri Enstitüsü.

Arslan, H. ve Altıntaş, G. (2014). Engellilerin çalışma yaşamına katılımını arttırarak toplumla kaynaşmalarını sağlamayı hedefleyen bir model önerisi. Çankırı $\mathrm{Ka}$ ratekin Üniversitesi Sosyal Bilimler Enstitüsü Dergisi, 5(2), 165-186. 
Baran, N. ve Cavkaytar, A. (2007). İşverenlerin zihin engelli bireylerin istihdamlarına ilişkin görüş ve önerileri. Illköğretim Online, 6(2), 213-225.

Çarkçı, Ş. (2011). Engellilerin mesleki eğitim ve istihdamı. Yayımlanmamış yüksek lisans tezi, Marmara Üniversitesi Sosyal Bilimler Enstitüsü.

Devlet İstatistik Enstitüsü Başkanlığı. (2002). Türkiye özürlüler araştırması 2002. Ankara: Devlet İstatistik Enstitüsü Matbaası.

Eren, A. (2010). Engellilerin iş yerinde çalıştırılabilmesi için yapılabilecekler üzerine bir araştırma. Yayımlanmamış yüksek lisans tezi, Maltepe Üniversitesi Sosyal Bilimler Enstitüsü.

Genç, Y. ve Çat, G. (2013). Engellilerin istihdamı ve sosyal içerme ilişkisi. Akademik Incelemeler Dergisi, 8(1), 363-394.

Gökmen, F. (2007). Türkiye'de özürlü haklarının gelişimi. Öz-Veri Dergisi, 4(2), 78.

Greenan, J. P., Wu, M. ve Black, E. L. (2002). Perspectives on employing individuals with special needs. The Journal of the Tecnology Studies, 27(1), 29-37.

Güneş, N. ve Akçamete, G. (2014). Özel gereksinimli olan bireylerin mesleki istihdamı: Çorum ili örneği. Ankara Üniversitesi Ĕ̈itim Bilimleri Fakültesi Özel Ĕ̆itim Dergisi, 15(3), 1-15.

Hasırcıoğlu, A. (2006). İşverenlerin özürlü istihdamına yaklaşımı (Sakarya örneği). Yayımlanmamış yüksek lisans tezi, Sakarya Üniversitesi Sosyal Bilimler Enstitüsü.

Karakuyu, A. (2017). Engelli bireylerin bakışıyla çalışma ve günlük hayattaki engelli sorunlar1. Kesit Akademi Dergisi, 3(12), 674-685.

Köksal, A. (2010). Türkiye'de engelli istihdamı ve bir araştırma. Yayımlanmamış yüksek lisans tezi, Bahçeşehir Üniversitesi Sosyal Bilimler Enstitüsü.

Kurt, B. (2020). Zihinsel engelli bireylerin istihdam sorunu ve çözüm önerileri. Yayımlanmamış yüksek lisans tezi, İstanbul Gelişim Üniversitesi Sosyal Bilimler Enstitüsü.

Mamatoğlu, N., Dökmen, Y. Z. ve Yıldırım, F. (2015). İşyerinde engelliye yönelik tutumlar ölçeği. Edebiyat Fakültesi Dergisi, 32(2), 183-204.

MEB. (2013). Mesleki becerilerin geliştirilmesi projesi (MESGEP): Dezavantajlı bireylerin eğitim ihtiyaçları analizi araştırma raporu. http://www.meb.gov.tr/meb iys dosyalar/2013 12/26051227 dezavantajlibireylerinegitimihtiyaclari.pdf

Orhan, S. (2013). Türkiye'de özürlü dostu istihdam politikalarl (durum analizi ve öneriler). Ankara: Çalışma ve Sosyal Güvenlik Eğitim ve Araştırma Merkezi Yayınları.

Özdemir. S. (2008). Türkiye'de hafif düzeyde zihinsel engelli bireylere meslek edindirme ve istihdamlarına ilişkin politikaların değerlendirilmesine yönelik yönetici, işveren ve veli görüşleri. Yayımlanmamış yüksek lisans tezi, Ankara Üniversitesi Sosyal Bilimler Enstitüsü.

Özgökçeler, S. ve Alper, Y. (2010). Özürlüler Kanunu'nun sosyal model açısından değerlendirilmesi. Işletme ve Ekonomi Araştırmaları Dergisi, 1(1), 33-54.

Öztürk, M. (2011). Türkiye'de engelli gerçeği. Müstakil Sanayici ve İşadamları Derneği Cep Kitapları, 30, 105.

Petty, D. M. ve Fussell, E. M. (1992). Employer attitudes and satisfaction with supported employment. Focus on Autism and Other Developmental Disabilities, 
$12(1), 15-22$.

Şahin, M. (2001). Türkiye'de sakatların çalışma hayatındaki sorunları. Yayımlanmamış yüksek lisans tezi, Gazi Üniversitesi Sosyal Bilimler Enstitüsü.

Toplu, A. (2009). Sosyal dışlanma perspektifinde Türkiye'de özürlü istihdamı. Yayımlanmamış yüksek lisans tezi, Gazi Üniversitesi Sosyal Bilimler Enstitüsü.

Tören, Z. (2014). Kamuda çalışan engelli kadınların problemleri. Yayımlanmamış yüksek lisans tezi, Marmara Üniversitesi Sosyal Bilimler Enstitüsü.

Yıldırım, A. ve Şimşek, H. (2013). Sosyal bilimlerde nitel araştırma yöntemleri. (9. Baskı). Ankara: Seçkin Yayıncılık. 